\title{
"I Am Black and Beautiful": A Black African Reading of Song of Songs 1:5-7 as a Protest Song
}

\author{
ROBERT KUlOBA WABYANGa (KyAMbOgo University)
}

\begin{abstract}
Adamo's article on Ebed-Melech's protest brings fresh insight into my earlier article on Song of Songs 1:5-7, prompting me to reread the text as a protest song (essay) against the racial stigmata that continue to bedevil black people in the world. The current article, using hermeneutics of appropriation, maintains the meaning of is as a black person, who in the Song of Songs protests against the racism, which transformed her status to that of a socioeconomic other. The study is informed by the contemporary and historical contexts of racial injustices and stigma suffered by Blacks for 'being' while Black. The essay investigates this question: In which ways does Adamo's reading of Jer 38:1-17 influence an African reading of Song 1:5-7 as a protest against racism? The article employs African Biblical Hermeneutics, as part of a creative and literary art in the protests against racism, to read the biblical text as our story-a divine story, which in the language of Adamo, has inherent divine power that can empower oppressed black people.
\end{abstract}

KEYWORDS: Song of Songs 1:5-7; Protest; "I am black but beautiful"

\section{A INTRODUCTION}

In a theopoetic rendition - archetypal of the undying flame of the African spirit-Song of Songs 1:5-7 is read as a lament of the black people, which showcases our beauty and challenges the oppressors as we chant, sing and ululate our worth, successes and joys even in the face and furnace of injustice. In it, we count our losses and appeal to a spirituality of hope that every knee that is placed on the black neck - preventing us from breathing - will be removed; that the knee of the oppressor shall bow and the oppressor will confess and seek spiritual forgiveness from every black soul lost in the chains and pains of injustice. The niche of this article is that the Bible is an African book, upon which we anchor our hope as portrayed in various works of David Tuesday Adamo. Adamo's article on Ebed-Melech's protest ${ }^{1}$ brings fresh insight into my earlier reading of

* Submitted: 28/04/2021; peer-reviewed: 22/09/2021; accepted: 22/09/2021. Robert K. Wabyanga, "I Am Black and Beautiful: A Black African Perspective of Reading Song of Songs 1:5-7 as a Protest Song," Old Testament Essays 34 no. 2 (2021): 588 609. DOI: https://doi.org/10.17159/2312-3621/2021/v34n2a16. 
Song of Songs 1:5-7. ${ }^{2}$ Among other things, Adamo argues that Ebed-Melech's protest against King Zedekiah and the royal family shows Ebed-melech's "courage, concern for justice, love, kindness and compassion." 3 To Adamo, Ebed-Melech's protest should be a "model for modern protests all over the world... that is filled with injustice." In light of Adamo's view, the current article reads Song of Songs 1:5-7 as a protest song (essay) in the contexts of not only historical injustices but also, more importantly, recurrent abuses inflicted on black people for "being" while black. Adamo's arguments inform the current study in three ways:

1) Ebed-Melech's protest is against injustices inflicted on other people. Ebed-Melech was not a direct victim of injustice but rather a sympathiser. It is from this framework that the article reckons with the efforts made by non-black people-like whites in South Africa, the United States and Europe-in protests like Anti-Apartheid and BlackLivesMatter ${ }^{5}$ (following the heinous murder of George Floyd by the United States authorities). Many non-black people, besides street protests and matches, have used their skills as musicians, journalists, academics, priests and so forth to expose and condemn racially motivated acts of injustice against black people.

2) Psycho-social motivation of the oppressor: Zedekiah and the nobles of Judah are fearful that the continued utterances of Jeremiah would weaken the spirit of Judah's armies and the people in the face of imminent Babylonian invasion. The nobles, puffed with pride, became afraid on hearing about the wave of change in the ancient Near East that was sweeping through Judah. Motivated by the ideological drive that Yahweh cannot disappoint his people, the nobles could not tolerate Jeremiah's utterances. Due to their fear, they arrested and condemned Jeremiah to prison as a way of containing him.

3) Protests, well directed, yield results. The audacity of hope exhibited by Ebed Melech caused change in the royal family-with King Zedekiah acting independent of the nobles - who ordered the release of Jeremiah. Protests cause embarrassment to the oppressors, who in turn would re-examine their ways in the face of public opinion and stop oppression.

1 David T. Adamo, “Ebed-Melech's Protest to King Zedekiah as a Model of Modern Protest Movement (Jr 38:1-17)," In die Skriflig 53(1).

2 Kuloba R. Wabyanga, "Song of Songs 1:5-7: The Africana Reading," JTSA 150/1 (2014): 128-147.

3 Adamo, "Ebed-Melech's Protest," 1.

4 Ibid.

5 Jeremy Sawyer and Anup Gampa, "Implicit and Explicit Racial Attitudes Changed during Black Lives Matter," Personality and Social Psychology Bulletin 44/7 (2018): 1039-1059. 
This article affirms that black people are subjects of their own struggles against all forms of discrimination and injustice. Using hermeneutics of appropriation, this article reads שְִׁׁוֹרָה אָנִי וְנָאוָה and the rest of Song of Songs 1:5-7 as a protest song against historical and contemporary injustices and stigma suffered by the race for 'being' while black - reality that has destined black people to be economic nobodies. ${ }^{6}$ The essay investigates the question: In which ways does Adamo's reading of Jer 38:1-17 influence an Africana reading of Song of Songs 1:5-7 as a protest against racism? The article employs African Bible Hermeneutics, as part of a creative and literary art in the protests against racism, to read the Bible text as our story - a divine story-which in the language of Adamo, has inherent divine power that can deliver the poor, the weak and the oppressed black people. ${ }^{7}$

\section{B METHODOLOGY}

As already hinted above, the study employs Hermeneutics of Appropriation (HA), as "promulgated" and championed by Temba Rugwuji. ${ }^{8}$ Hermeneutics of Appropriation probes a thematic literary and rhetorical analysis of the text and appropriates it to the reality of the reader. In their analysis of appropriation as a hermeneutic tool, Paul Ricoeur and John B. Thompson note that in any setting, writings are written for anybody to read and any reader can be a potential audience. This is the unknown reader whom the text procures, ${ }^{9}$ different from the intended audience of the writer of the text. This approach is necessary compared to the Contextual Bible Hermeneutics which mandates the reader to have a good grounding of the context of the text. ${ }^{10}$

It suffices to point out that though the singer accentuates her colour as

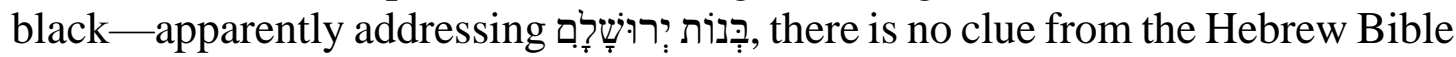
that black people were racially discriminated against or stigmatised in the Bible world. This makes it difficult for scholarship to situate the text in a proper sociocultural context for analysis. The study is a creative reading of the Bible text, contributing to other performing, music and literary arts in academic discourses

6 Wabyanga, "Song of Songs: The Africana Reading," 131.

7 David. T. Adamo, "What Is African Biblical Hermeneutics?" Black Theology 13/1 (2015): 66-68; David T. Adamo, "African Background of African American Liberative Hermeneutics," African Journal of Biblical Studies 20 (2004): 3-28.

8 Temba Rugwiji, "The Quest for Hermeneutics of Appropriation as a Thematic Approach for Critical Biblical Interpretation," HTS Teologiese Studies/Theological Studies 76(1); cf. Temba Rugwiji, "Appropriating Judean Postexilic Literature in a Postcolonial Discourse: A Case for Zimbabwe" (PhD thesis, University of South Africa), 2013.

9 Paul Ricoeur, "Appropriation," in Hermeneutics and the Human Sciences: Essays on Language, Action and Interpretation (ed. John B. Thompson; Cambridge: Cambridge University Press, 2016), 144.

10 Rugwiji, "The Quest for Hermeneutics of Appropriation." 
against injustices. It de-romanticises Song of Songs and reads the text from the frameworks of racial injustice.

\section{THE TEXT}

Wabyanga's essay on Song of Songs 1:5-7, as cited above, offers a detailed analysis of the text, which will not be repeated here. This section problematises

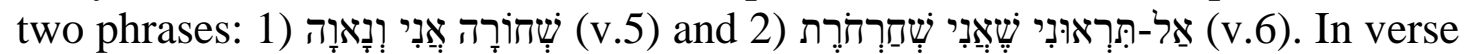
5, שִׁחוֹרָה (from the root is the adjective by which the singer identified herself

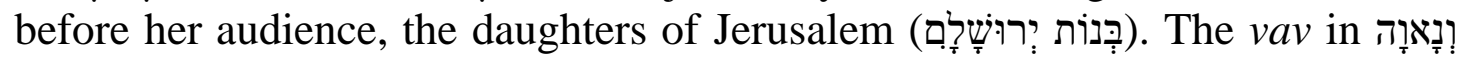
can be read conjunctively (as and) or disjunctively (as but) unlike in the earlier reading which preferred a disjunctive rendition. The term שִׁחוֹרָה denotes black colour (Song of Songs 5:11, Zech 6: 2,6). The positioning of this word at the beginning of verse 5 is not accidental but emphatic. It suggests the Poet's intention to the audience. This clause can thus be translated as "I am black and

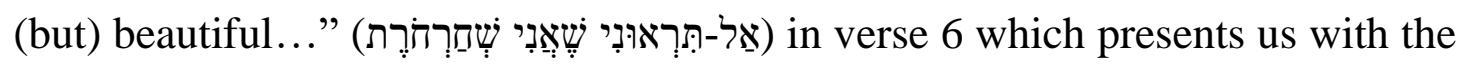

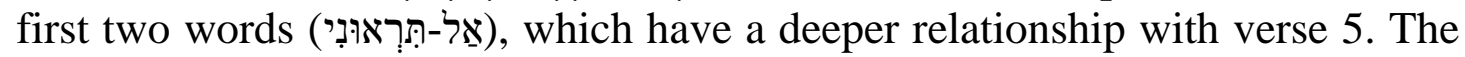

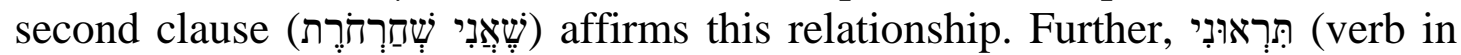
second person plural with a pronominal suffix for first person singular) morphologically seems to be a package of word-play on the roots of (stare or look) and ירא (fear in qal and terrified in piel (cf. 2 Sam 14:15). ${ }^{11}$ Understood

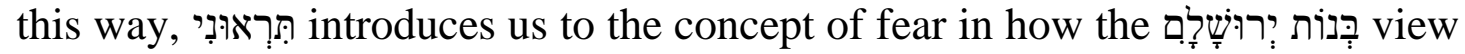
the Poet, hence, the translation/interpretation, "Don't stare at me with fear because my skin is black!"12

The constructed reading of these verses, thus, would suggest: "I am black and (but) beautiful... Don't stare at me with fear because my skin is black!" This is to say that the issue at stake is the skin colour of the singer in the face of disparaging attitudes of her audience. The song is a protest against the dominant

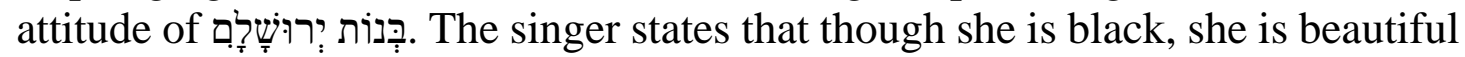

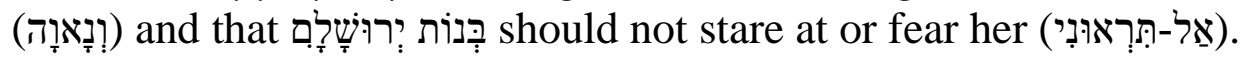

Whether the black character was the daughter of Pharaoh ${ }^{13}$ or the Shulamite from Shulem, ${ }^{14}$ there is a possibility that she was Solomon's wife. Thus, it is possible that her presence in the Solomonic court enlisted envy and

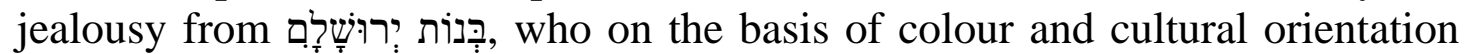
scorned the singer. We read of similar murmuring in Num 12:1-10 and the resultant punishment of Miriam. In his many works, Adamo has thoroughly

11 Wabyanga, "Song of Songs 1: 5-7," 130.

12 Ibid.

13 Victor Sasson, "King Solomon and the Dark Lady in the Song of Songs," Vetus Testamentun 39/4 (1989): 407.

14 Chana "Shulammite: Bible," JWA. https://jwa.org/encyclopedia/article/shulammite-bible. 
treated the subject of black people and their presence in the Bible. ${ }^{15}$ In the Bible, a black person is referred to as a Cushite (Num 12:1, Jer 13:23 and 2 Kgs 19:9). Edward Ullendorff, from a different perspective, has equally done a commendable work on the references of Cush in the Bible and extra-biblical sources. Cush is mentioned about 56 times in the Bible. In many translations, especially those based on the Septuagint, Cush is rendered Ethiopian and it is used to refer to all people of dark skin. ${ }^{16}$ In recent studies, Knut Holter has argued that although not all the 56 occurrences of Cush in the Bible may refer to black Africans but to other communities like the Kassites in Babylon or the tribal groups that lived south-west of Judah, the majority of references to Cush are to black Africans. ${ }^{17}$ Holter, in his analysis of Cush in the Bible, upholds a view that black people are not a modern-era addition in the biblical story of salvation but a historical race that was, hitherto, known in all Bible collections (Pentateuch, historical books, the Prophets and wisdom literature) as proactive subjects in the ancient Near Eastern and Bible polity. ${ }^{18}$ Other scholars, who have examined the same subject include James Warden, who points out, among other things, the undisputable position of black people in Christian theology. ${ }^{19}$

\section{CONTEXT OF THE STUDY:}

In this section, the focus is not on the historical or cultural context of the biblical texts but on racial discrimination and stigmata which have taken diverse forms. Racism against the black race and the resultant mistreatment is now pandemic in magnitude. There is an outcry by black people against racial injustices that dehumanise them - especially in many western cities. "What does it mean to be black in the world?" is a question which has been asked endless times. In his recent album (2020), Absent Minded asks, "What does it mean to be black?" Sandra Gathmann, an Al-Jazera journalist, asked a similar question, "What does

15 David T. Adamo and E. F. Eghwubare, "The African Wife of Abraham (Gn 16:116; 21:8-21)," OTE 18/3 (2005): 455-471; David T. Adamo, "The Portrayal of Africa and Africans in the Book of Jeremiah," In die Skriflig 52/1, a2259. https://doi.org/10.4102/ids.v52i1.2259.

16 Edward Ullendorff, Ethiopia and the Bible, Schweich Lectures (London: The British Academy and Oxford University Press, 2009), 5-6.

17 Knut Holter, "Africa in the Old Testament," in The Bible in Africa: Transactions, Trajectories and Trends (ed. Musa Dube and Gerald O. West; Boston: Brill, 2000), 575.

18 Holter, "Africa in the Old Testament," 579.

19 James H. Warden, Black in the Bible: The Original Roots of Men and Women of Color in Scripture (London: AuthorHouse, 2006). 
it mean to be black in America?"20 as does Maquita, ${ }^{21}$ Brunsma and Rockquemore $^{22}$ and many other voices. In the face of these injustices, black people have always asked the obvious question to which they know the answer, "Is it because I am Black?" This question is well epitomised in the musical works of Syl Johnson and Tiken Jah Fakoly in 1969 and 2015 respectively, which ask, "Is it because I am Black?" In a more recently documented voice, Dr. Suzan Moore is presented as not only critically ill with a Covid-19 related illness in an Indianan hospital but also as suffering mistreatment in the hands of racist doctors and nurses. In a clearly frail yet trained voice, she said, "If I was White, I wouldn't have to go through that... I'm being treated like a drug addict yet he (the doctor) knows I am a physician... This is how black people get killed." 23 Though Moore did not ask the question, she gave an answer to it. Her mistreatment is because she is Black. Moore's lament as well as the outcries of other black people who have faced ugly racism accentuates the idea of "I am Black" as a personhood, an identity and a consciousness, which is being violated, abused and degraded.

It is this context of violation against "who I am-I am black" that Blacks and their sympathisers have engaged in protests, refusing the foreign narrative that portray blackness as evil, ugly, sinister etcetera but rather showcasing the idea that Black is beautiful, noble and gallant. Tribute is given to the activities of Stephen Biko in his 'Black is beautiful' campaign during the anti-apartheid protests in South Africa ${ }^{24}$ and to Martin Luther King, Jr. who cried out, "Yes I am black and proud of it! I am Black and Beautiful!"25

The genesis of racial aggression against black people is traced historically to European imperialists and colonialists that found legitimacy in anthropological theory of social Darwinism to raid black Africans from the continent, enslave them in Europe and the Americas and eventually colonise their continent. Social Darwinism elevated the white race as superior to other races. Blacks were portrayed as inferior en toto, requiring the paternal rule of

20 Sandra Gathmann, What Does It Mean to Be Black in America? Al Jazera [viewed on 15 July 2020]. Online: https://www.youtube.com/watch?v=4NgkJJzzk8Q.

21 Maquita Peters, "Being Black in America: 'We Have a Place in This World Too"" [cited on 15 July 2020]. Online: https://www.npr.org/2020/06/05/867060621/beingblack-in-america-we-have-a-place-in-this-world-too.

22 David L. Brunsma and Kerry Ann Rockquemore, "What Does "Black" Mean? Exploring the Epistemological Stranglehold of Racial Categorization," Critical Sociology 28/1-2 (2002): 101-121.

23 John Eligon, "Black Doctor Dies of Covid-19 after Complaining of Racist Treatment," The New York Times [cited 12 March 2021]. Online: http://www.nytimes.com/2020/12/23/us/susan-moore-black-doctor-indiana.html.

24 Shannen L. Hill, Biko's Ghost: The Iconography of Black Consciousness (Minneapolis: MUP, 2015), 4.

25 Quoted in Warden, Black in the Bible. 
white people in order to develop ${ }^{26}$ and often, black people were not accorded same respect as whites. For instance, while Britain was willing to grant dominion status to its old colonies of white settlers in Canada, Australia and New Zealand, black people in West Indies were denied the same. ${ }^{27}$

Additionally, European Christian missionaries manipulated African religious sensitivities with eschatological imaginations. In the preaching about the imminent return of Jesus Christ, all the dead will resurrect. Those who died in Christ will resurrect first, to receive favourable judgement and go to heaven where they will be crowned heirs to the throne-reigning with Jesus. Heaven was idealised as a place of bliss, radiant with beams of righteousness from the throne, full of white angels, golden streams and streets and abject happiness, contentment and peace. Heaven was preached as the destiny for those who "leave everything" and follow the missionary preaching. Hell on the other hand was constructed and idealised as the home of Satan, a place of doom, dark, with unquenchable fire where non-Christians are destined. Residents of hell are in perpetual agony of torment and suffering. Satan (with his angels) was portrayed as a black animal-like creature with a formidable look of sharp nails and canine teeth for feasting on human souls.

This gas-lighting approach on Africans served missionary and colonial racist interests, as indeed so many black people came to believe that their own story, names, images, culture and religion were evil and they were hell bound if they maintained their pride and identity. African names were labelled as evil and in order to enter heaven, one had to be given a new western name at baptism. ${ }^{28}$ This resonated with the trans-location of black people into the Americas, who upon arrival as slaves were presumed nameless until they were given names for the convenience of the slave owners. ${ }^{29}$ Both the trans-location and naming had significant alienation effect on black people.

That colonialism was racism in its most brutal form was expressed differently in African colonies but the common denominator was the line separating Whites from Blacks. Racism was openly justified throughout colonial

26 Robert J.C. Young, Postcolonialism: A Very Short Introduction (New York: OUP, 2003), 3.

27 Walter Rodney, How Europe Under-developed Africa (London: BogleL'Ouverture, 1973), 213-214.

28 It should be noted that African names carried much theological and philosophical significance not only to the name bearer but also to the entire family and clan he/she belongs.

29 See Laura A. Lopez, "Who Named Slaves and Their Children? Names and Naming Practices among Enslaved Africans Brought to the Americas and Their Descendants with Focus on Brazil," Journal of African Cultures and Studies 27/2 (2015): 159-171; Cynthia Lyles-Scott, "A Slave by Any Other Name: Names and Identity in Toni Morrisons's Beloved," Journal of Onomastics 56/1 (2008): 23-28. 
Africa especially in British and German colonies. In British colonies, it was said that one white man was equal to or more than thousands of Africans. This was reflected in resource allocation whereby minority white settler communities in Africa were allocated vast domains of land and the vast majority of Africans were confined to concentration camps like the Bantustans in South Africa. It was the same case in Kenya and Rhodesia. As such, Africans were deprived of their independence and sources of livelihood and were subjected to forced labour to the benefit of the colonisers.

Furthermore, racial stigmata against Blacks exist because black people are seen as a threat in white spaces. Some Whites absorb the presence of Blacks within their fear and anxiety systems. ${ }^{30}$ Through these mechanisms, unless an individual is subjected to interventions of corrective measures such as appropriate formal education, racial interactions and exposure ${ }^{31}$ to deconstruct conscious and non-conscious conditioning and responses to black people, an individual's fears may develop to the level of anti-social behaviours, which, in the context of this study, is racism. In a Kurt Riezler's study of social psychology of fear, findings show that human fear is influenced by the loss of health, wealth, family and social status. Human beings are conditioned to be anxious, suspicious and fearful of "something" (that which is known) and "some-thing" (that which is unknown) that might offset the balance, ${ }^{32}$ in any of the aforementioned fundamental elements.

The relationship between Blacks and Whites is characterised by fearoften the fear of something or some-thing - that can happen and offset the social or emotional balance. This fear is both inherited and learnt. ${ }^{33}$ Since slavery and colonialism constructed racial hierarchies, the architects of this hierarchical complex had expectations, which were ideologically protected. Whites in many western societies would always exhibit fear and anxiety when a black person-

30 See Joseph E. LeDoux, "Coming to Terms with Fear," PNAS 111/8 (2014): 2871; Jaak Panksepp, "Fear and Anxiety Mechanisms of the Brain: Clinical Implications," in Principles of Medical Biology (ed. E. Edward Bittar and Neville Bittar: Elsevier, 2000), 155-177.

31 Several scholarly findings on what has been called contact hypothesis suggest that racial contacts between whites and blacks yield positive attitudes especially among college students. See Lee Sigelman and Susan Welch, "The Contact Hypothesis Revisited: Black-White Interaction and Positive Racial Attitudes," Social Forces 71/3 (1993): 781-795; Marylee C. Taylor and Peter J. Mateyka, "Community Influences on White Racial Attitudes: What Matters and Why?" The Sociological Quarterly 52/2 (2011): 220-243; Mary J. Fischer, "Interracial Contact and Changes in Racial Attitude of White College Students," Social Psychology of Education 14 (2011): 547-574.

32 Kurt Riezler, "The Social Psychology of Fear," The American Journal of Sociology 49/6 (1944): 489.

33 See R. Nicholas Carleton, "Fear of the Unknown: One Fear to Rule Them All?" Journal of Anxiety Disorders 41 (2016): 6-7. 
perceived to be lower in hierarchy - crossed the ideological racial boundary. The result was the use of state systems and personal energy to contain the "intruder," who is often portrayed in illicit terms of criminality. ${ }^{34}$ This fear either stems from a deep seeded guilt consciousness due to collective historical injustices or is learnt through propaganda and conspiracy theories from the past generations that aimed at maintaining the status quo of Black subjugation. In the United States, following the abolition of slavery, there was fear and suspicion of "something" and "some-thing" in the White consciousness that became associated with the freed black slaves. To deal with this fear and anxiety, a discriminatory, highly mechanised justice system against black people was put in place, ${ }^{35}$ which still daunts and demonises black lives in beastly ways.

In colonial Africa also, colonialists crafted means of managing the people for fear of a potential backlash from Africans - the people whose hospitality had been abused. In settler colonies like Kenya, Algeria and Southern Rhodesia, concentration camps were created and managed by colonial police to monitor and control Africans. In South Africa, fear of Africans took the form of apartheid, which meant separateness. To avoid Africans, separate spaces were created for Whites vis-à-vis Blacks. In the United States, the progress of Blacks has been treated with fear and anxiety. In his 1998 article, Litwark demonstrates how white Americans, especially in the Southern States, exhibited great fear and antipathy to black people's education. They burnt black schools and molested white teachers who taught in black schools. ${ }^{36}$ Whites wanted basic education for Blacks that would perpetuate racial hierarchy but not an educational model that would break their ideological paradigm. Ironically, the same people, who maintained that black people had inferior cognitive capacities (and thus did not need formal education), feared that educating Blacks to become lawyers,

34 Glenn C. Loury, "Racial Stigma and Its Consequences," Focus 24/1 (2005):1-2; Iyiola Solanke, "The Stigma of Being Black in Britain," Identities 25/1 (2018): 49-54; Robin A. Lenhardt, "Understanding the Mark: Race, Stigma and Equality in Context," New York University Law Review 79 (2004): 803-931; Caroline Howarth, "Race and Stigma: Positioning the Stigmatized as Agents, not Objects," Journal of Community and Applied Social Psychology 16/6 (2006): 442-451; Angela Neal-Barnett, "To Be Female, Anxious and Black," Anxiety and Depression Association of America [cited 10 July 2020]. Online: https://adaa.org/learn-from-us/from-the-experts/blogposts/consumer/be-female-anxious-and-black; Elijah Anderson, "This Is What It Feels Like to Be Black in White Spaces," The Guardian [cited 10 July 2020]. Online: https://www.theguardian.com/commentisfree/2018/jun/09/everyday-racism-americablack-white-spaces.

35 Elizabeth Hinton, LeShae Henderson and Cindy Reed, An Unjust Burden: The Disparate Treatment of Black Americans in the Criminal Justice System (New York: Vera Institute of Justice, 2018): 2-3.

36 Leon F. Litwark, “The White Man's Fear for the Educated Negro: How the Negro Was Fitted for His Natural and Logical Calling," The Journal of Blacks in Higher Education 20 (1998): 100. 
teachers, doctors and clergymen would create a new breed of black people who have same intuitions, ambitions and expectations as Whites_- "a bad imitation of the Whites." ${ }^{37}$ Litwark reports that the sight of Blacks carrying books was perceived with the same fear as the sight of armed Blacks. ${ }^{38}$ In the liberation of black people, Whites were anxious and fearful that their elevated racial status would be challenged or come to end and probably feared that their fate would be reversed when the balance of power shifted to the Blacks. Indeed black education was to some a foolhardy move - akin to "placing a loaded magazine riffle in the arms of a chimpanzee." 39

The abolition of slavery in the United States created new polarised spaces (white spaces versus black spaces). One of the products of the Civil Rights Movement was the upward mobility of Blacks into the settings previously occupied by Whites, albeit they were poorly received. Black people of middleincome status, who left the ghetto areas for better residential places inhabited mainly by Whites were always perceived in ghetto terms and often avoided by their white neighbours, who choose to move to other places or sell their homes because of the new black neighbour. ${ }^{40}$ This serves to exemplify the depth of fear, resentment and anxiety some white people have for people of black colour. As Anderson notes, despite the affluent status acquired by some black people, their aura of respectability and reception remains minimal in white spaces. Though courteous, law-abiding and progressive, their existence as Blacks makes them indistinguishable from other lowly Blacks, who reside in local ghettos and are usual victims of racial profiling and police brutality. ${ }^{41}$ That some Whites treat "blackness in a person as a master status that supersedes their identities as ordinary law-abiding citizen" is well illustrated in the 2004 Hollywood movie called Crash. In one of the scenes, Ryan, a white policeman in the pursuit of a stolen SUV vehicle, intercepts a middle-income black couple-Cameroon who works as TV director and his wife Christine. Ryan, in a racially motivated instinct sexually assaults Christine in full view of her disempowered husband who is also subjected to verbal insults. Christine is outraged at her seemingly docile husband for not coming to her salvation at the time she thought he should have acted as the man. Cameroon in an angry voice tells Christine, "I think you don't know what it means to be Black in this country."42 Activated racial stereotypes are also epitomised in the case of Dr. Susan Moore above. As Anderson says of black people - whether hailing from the ghetto or the middle-

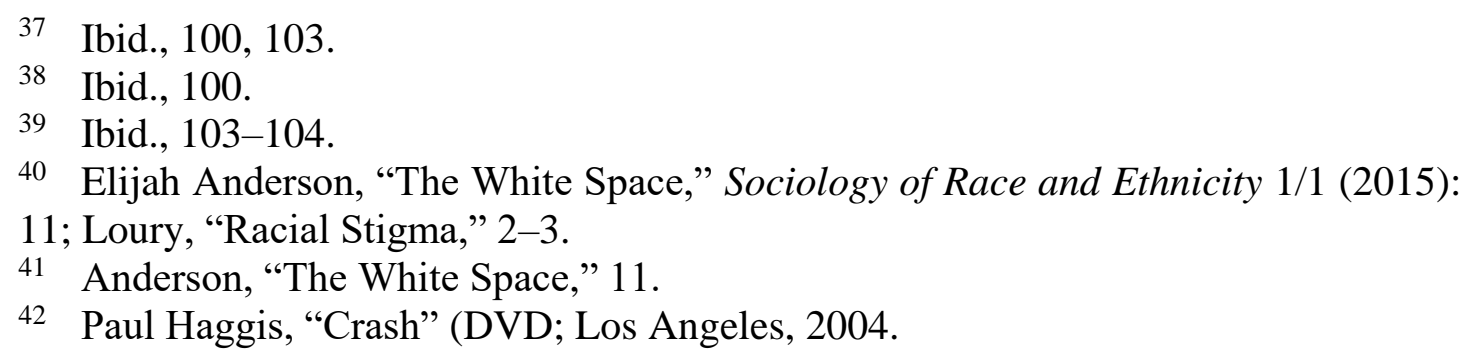


class suburbs, "the black skin designates them as being from the ghetto." 43 The black ghetto is often perceived by Whites in negative terms and in association with criminality, poverty, gangs, drug dealers, total lawlessness and all sorts of vices. Blacks, as Anderson also concurs, are stereotyped in relation to the ghetto, ${ }^{44}$ which is antithetical to white spaces and privileges. From this perspective, the white supremacist's perception of any black person activates racist stereotypes that associate blackness with inferiority, poverty and unqualified status irrespective of social status and nationality. Viewed this way, the plight and disparaging treatment of black people as inferior in the west, constitutes the problem of all Blacks everywhere in the world.

In some quarters, the line between Whites and Blacks is secured to maintain racial status quo. Security operatives including police and domestic dogs are trained in a racist way to be suspicious of black people. In some places, black people are harassed for being Black. The lament of one college student in the United States illustrates this agony:

Why is it that so many White people fear Black men? Whenever I learn about another Black man dying and no one is held accountable, I cannot help but to feel angry. I am furious about Black men being devalued in the United States — our lives are just as valuable as anyone else's. I constantly have to stay on alert because I do not know when police officers will pull me over, or start following me around in a particular location. I have firsthand experience with White people thinking I am a criminal or that I am in a gang. If I do not walk around with a smile on my face, it often changes the dynamics of my day. I am no longer the "sweet, young man" who always smiles-I am looked at as if I am hostile or angry for no reason. ${ }^{45}$

The racial stigmata against Blacks serve to energise and orient the white audience with what Solanke has called hyper-invisibility versus hyper-visibility. Racial stereotypes are to maintain Blacks' hyper-invisibility in politics, education and the civil service as well as their hyper-visibility in criminality, slave-like life, marginality, poverty, low life and ignorance. It is from these frameworks that black Africans are treated as a low race in racial hierarchy. Solanke, ${ }^{46}$ Turner and Graverholz, ${ }^{47}$ respectively, have exposed the hyper-

43 Anderson, “The White Space," 12.

44 Ibid., 19-20.

45 Dmitric C. Westbrook, “Opinion Editorial: Why Is It That So Many White People Fear Black Men?" College Student Affairs Leadership 1/2 (2014): Article 4.

46 Solanke, "The Stigma of Being Black in Britain," 51-52.

47 Claudine Turner and Liz Grauerholz, "Introducing the Invisible Man: Black Male Professionals in Higher Education," Humboldt Journal of Social Relations 1/39 (2017): 223. 
invisibility of black professionals in academic ranks in Britain and the United States.

On the other hand, as a consequence of racial stigma, black people have often navigated this rough terrain in many ways. Sadly, some see blackness as undesirable given that the emotional and political economy of being Black elicits negative perceptions in the public mind. ${ }^{48}$ Some black people, especially women, have ended up applying skin bleaching and lightening creams, which endanger their health. ${ }^{49}$ Coupled with other manifestations such as wearing long artificial hairs and behavioural mimicry, the attitude held is a sheer mockery of nature and the rich Black heritage and ancestry. It serves to nourish racial stereotypes of the oppressor as the oppressed, in a self-loathing manner, which tries to define beauty from a foreign paradigm and the perspective of the oppressor.

Similarly, black people also navigate racial stereotypes fearfully. In their social outings-especially as they traverse White spaces-black people approach white people with fear of racial discrimination. Blacks "tend to assume that a white person is likely to be racially insensitive, if not openly prejudiced and before giving the person full trust, they hesitate." 50 This is because of the mental conditioning of black people that decent or good white people who do not have negative opinions against Blacks are very rare to find. Blacks, therefore, consciously take time to associate with those Whites who are not likely "to exhibit the kind of racial animus against them which they strongly associate with most other white people." "It is a major problem for Blacks "to figure out which white persons are decent and trustworthy and which ones are covertly racist; they worry about misplacing their trust, as they commonly experience 'let downs' and racial setbacks." Where black people find their relationship with Whites problematic, "they tend to disengage with white people both in public and in private, keeping such relations somewhat superficial." 52 I experienced this scenario while a student at one prestigious university in Israel. In a class of many white students from the United States and Europe, only two of us were black students - I who hail from Africa and my fellow black named S, who came from the United States. Mr. S was a very quiet and often lonely student. He moved alone and was seldom in the company of other Americans. Racial affinities drew us together as friends but the friendship lasted for just a few days for reasons I did not understand then. Mr. S was betrayed by my indiscriminate and blunt feelings about acts of racism exhibited by mainly white American students. Unlike me, an African, S avoided his white American counterparts at all costs. Unlike me, $S$ apparently had a sensitive intuition to all signs of racism given his

48 Solanke, "The Stigma of Being Black in Britain," 52.

49 Ibid., 52.

50 Anderson, "This Is What It Feels Like."

51 Ibid.

52 Ibid. 
background. I often experienced racism too but my expectations were oriented differently from Mr S's. Moreover, I think a clear African identity shaped my focus and expectations compared to my black brother whose own identity was deeply wounded by systematic racism and American history. With the guidance of my academic supervisor, I was less responsive to my incidental racist manifestations.

\section{E ANTIRACISM PROTESTS AS A CONTEXT}

Protests and responses of diverse nature and magnitudes against racist injustices suffered by black people around the world have been observed in part. Blacks, aided by decent and good non-Blacks, have protested against racist attitudes of mostly white people using various avenues. In his analysis of protests, Adamo has named three types but he gives prominence to two types of protests against injustices in the contemporary world. These are prophetic protests, political protests and sacramental protests. ${ }^{53}$ According to Adamo, political protests and sacramental protests are the most popular forms of protests in the West African context. There is no doubt that protests against racism have also taken these dimensions but in my opinion, there are other forms of protests, which Adamo has not mentioned such as intellectual protest (for lack of proper word). According to the Online English Dictionary, a protest is "an expression or declaration of objection, disapproval, or dissent, often in opposition to something a person is powerless to prevent or avoid." ${ }^{\circ 4}$ By way of appropriation, especially in the context of injustice, intellectual protests are, thus, the use of scholarship and academic tools to denounce and oppose injustice by complaining strongly about it in academic and journalistic discourses. These forms of protests are the result of creative thinking by individuals and sometimes are protected under intellectual property laws. Intellectual protests begin with identifying, problematising and interrogating the dominant issues that affect humanity. Questions asked are the What, Why and How?, aimed at bringing out issues to levels of awareness for appropriate political action and social change.

Various scholarships and professions have articulated the problem of racial injustice against Blacks in various ways. For instance, in her question, "What can be done to change the political and emotional economy of (Blacks)?," Solanke proposes increased numerical visibility of black professors and academics in higher institutions of learning. In her view, this would change the social imaginary surroundings in which black people find themselves. ${ }^{55}$ Maria W. Stewart, teacher, lecturer and writer in 1834, bewailed and mourned for Africa against America's "foul and indelible stain" and declared America as a nation

53 David T. Adamo, "Ebed-Melech's Protest," 3-5.

54 Protest [Cited $23 \quad$ September 2021]. Online:

https://www.dictionary.com/browse/protest.

55 Solanke, "The Stigma of Being Black in Britain," 52-53. 
marked "for thy cruel wrongs and injuries to the fallen sons and daughters of Africa." She noted that God would plead the case of the oppressed against the oppressor and would provide "charity" even if it was a "small return" for the suffering of black women and men. In her argument for reparations, Stewart asserted: "We will tell you that it is our gold that clothes you in fine linen and purple and causes you to fare sumptuously every day; and it is the blood of our fathers and the tears of our brethren that have enriched your soils. AND WE CLAIM OUR RIGHTS!" 56 Turning her attention to the black people, Stewart said that it is not the colour of the skin that makes the person, but it is the principle formed within the soul and urged African Americans to develop their talents and intellect, live moral lives and devote themselves to racial activism. ${ }^{57}$ In her poetic appeal, Stewart addressed the women thus:

O ye daughters of Africa, awake!

Awake! Arise! No-longer sleep nor slumber,

but distinguish yourselves

Show forth to the world that you are

endowed with noble and exalted faculties. ${ }^{58}$

Stewart did protest not only against the racial ill-treatment of Blacks before and during her time, but also against the conformist and ambivalent attitudes of some black people due to many years of enslavement and ideological conditioning. Stewart, in her protests, affirmed that Blacks are beautiful and need to see their beauty and worth through resistance against slave labels and conditioning and their nobility from a different perspective.

Music and performing arts have been a popular platform for protesting racial marginalisation. For instance, with the birth of what came to be called the Black is Beautiful Movement, African Jazz-Art Society and Studios (AJASS) organised a fashion show in 1962 in New York City in which black women called Grandassa Models wore their Afro hair and clothes with pride as they cat-walked in a show of protest against how black women were portrayed in Ebony magazines in America. ${ }^{59}$ In the 1970s, various songs were composed such as "Young, Gifted and Black:

56 Quoted in Dwight N. Hopkins, "Enslaved Black Women: A Theology of Justice and Reparations," in Beyond Slavery: Overcoming Its Religious and Sexual Legacies (ed. Bernadette J. Brooten and Jacqueline L. Hazelton; New York: Palgrave Macmillan, 2010), 287.

57 Christina Henderson, "Sympathetic Violence: Maria Stewart's Antebellum Vision of African American Resistance," MELUS 38/4 (2013), 52-75.

58 Marilyn Richardson (ed.), Maria W. Stewart, America's First Black Woman Political Writer: Essays and Speeches (Indiana: Indiana University Press, 1987), 30.

59 Precious Adesina, "The Birth of the Black Is Beautiful Movement," BBC [cited 15 July 2020]. Online: https://www.bbc.com/culture/article/20200730-the-birth-of-theblack-is-beautiful-movement. 
"Black is the colour of my skin, and Black is the life that I live in. I am so proud to be the colour that God made me. I just got to say Black is my colour, wouldn't be any other oh no." 60

In their study, Anna Rastas and Elina Seye examine the activities and roles of musicians in anti-racism protests in Finland. ${ }^{61}$ Many white activists musically protested against racism in history. ${ }^{62}$ Similarly, the media industry has been vocal in addressing the problem of racism. Print and broadcast media as well as local and international media such as CNN, BBC and Al Jazeera, etcetera have aired the problem of racism in news bulletins and different specialised programs. This reality is acknowledged also in many scholarly works. ${ }^{63}$

In this context, parodying Song of Songs 1:5-7 is a form of resistance whereby the author protests against slurs that define blackness in terms of hyperinvisibility and hyper-visibility. This is a contribution to the diversity of African Biblical Hermeneutics in trajectories of reading the Bible from the perspectives of theopoetic and theomusical renditions. It further affirms that we are visiblewe are black and beautiful and we cannot veil ourselves.

\section{F ANALYSIS AND CONCLUSION}

As argued elsewhere, Song of Songs 1:5-7 is a text that resonates very well with the plight of Africans, who for centuries have suffered racial injustices through slavery, imperialism, colonialism and neo-colonialism. The effects of slavery and colonialism can be summed up as total deformation for both Blacks and Whites - a deformation which polarises and defines modern day socio-economic and political egos and identities of Blacks and Whites. While there was a quantum socio-economic change in the sphere of whiteness, there was a huge slump in the socio-economic evolution of the entire black race-home and away. To Whites, this historical past constitutes an embarrassment but to Blacks, the assault inflicted great damage on the essence of blackness as a race, mind and

60 Solanke, "The Stigma of Being Black in Britain," 50.

61 Anna Rastas and Elina Seye, "Music and Anti-Racism: Musicians' Involvement in Anti-Racist Spaces," Popular Music and Society 42/5 (2019): 592-610.

62 See Arwa Haider, "The Art of Protest: White Riot: The Music Activists Who Took on Racism," BBC Documentary [cited 14 July 2020]. Online: https://www.bbc.com/culture/article/20200819-white-riot-the-music-activists-whotook-on-racism.

63 Marcus Burke, "How the Media and Entertainment Industry Is Addressing Systematic Racism," World Economic Forum [cited 15 July 2020]. Online: https://www.weforum.org/agenda/2020/07/how-media-and-entertainment-advertisingconsumer-products-sports-industry-is-addressing-systematic-racism/; T. Bjorgo Role of Media in Racist Violence, in Racist Violence in Europe (ed. T. Bjorgo and R. Witte; London: Palgrave Macmillian, 1993); Francis B. Nyamnjoh, "Racism, Ethnicity and the Media in Africa: Reflections Inspired by Studies of Xenophobia in Cameroon and South Africa," Africa Spectrum 1 (2010): 57-93. 
identity. It is an experience that transformed a "Black person to a suppressed other often in the second-class position." 64 Although David T. Adamo in his reading of Ebed-Melech's protest in Jer 38:1-17 does not mention intellectual protest, his works offer the basis for reading the Hebrew Bible in protest discourses against oppression. In the current article, Song of Songs 1:5-7 is read creatively as an intellectual protest against racial injustices. Reading the texts from such a perspective brings to the fore three important aspects: 1) The oppressed, 2) The oppressor and 3) The sympathiser. Unlike in Jer 38:1-17, where the oppressed (Jeremiah) remains silent in his oppression (although is audible elsewhere as a weeping prophet e.g. in Jer 11:18-20;12:1-4; 15:10; 17:14-18; 18:18-23.), the oppressed in Song of Songs speaks out against injustice. In the case of Jeremiah, it is the sympathiser who plays the critical role of protesting the arrest and incarceration of the prophet by King Zedekiah and his royals. Importantly, the oppressor (King Zedekiah) in the Jeremiah text is converted to one of the sympathisers, thanks to Ebed-Melech's protest.

From the perspective of Song of Songs 1:5-7, protest against injustice is the responsibility of the oppressed. The oppressed in the Song of Songs is not contained. She is assertive! She uses the music podium to sing of her worth with pride. She is boastful; she is black and beautiful. That statement, "I am black and beautiful," is important in protests in contexts where beauty is understood from a white perspective that regards the black colour, hair and face or figure as ugly. Stephen Biko echoes Song of Songs with the slogan, "Black is Beautiful," which calls blacks back to their human roots and dignity. ${ }^{65}$ From a psychological perspective, some black people developed internal racism against themselves when they internalised beauty through whitist frameworks. This act of selfloathing is well represented by Morrison Toni in her novel in which she presents a black girl, Pecola, whose desire to change her appearance to white drove her to a state of insanity. "I "I am black and beautiful" in Song of Songs 1:5-7 is an affirmation that also protests against foreign racist paradigms of beauty. It provides a framework for Africans to value, appreciate and assert their beauty, pride, strength and humanity as James Brown sang, "Say It Loud: I am Black and I am Proud." 67 To embrace western notions of beauty is to inflict severe damage on African ancestry and heritage and worsen the psychosocial and intellectual dislocation experienced by the people. In the South African model of protests, affirmation was given to blackness in what came to be called the Black Consciousness Movement (BCM). In BCM protests, protesters refused to keep silent in the face of oppression by the racist regime of apartheid but asserted and

64 Wabyanga, "Song of Songs 1:5-7," 135.

65 Hill, Biko's Ghost, 4.

66 Toni Morrison, The Bluest Eye (New York: Vintage Book International, 2007).

67 Quoted in Hill, Biko's Ghost, xviii. 
expressed in song their rights to be black with the slogan, "Black is beautiful." In the rhythm of Song of Songs 1:5-7, it can be argued that blackness should be sung in its own right, as the colour of beauty and novelty that is God given.

Those sympathise with anti-black oppression are a key ally in black protests. This does not discount the fact that there are some people who give lip service without inner commitment to dismantling racist structures. The sympathisers in this case are those non-Blacks who have demonstrated their support for anti-racism struggles through activism as well as financial and logistical resources. These are "the genuine good Whites," who are rare to find, according to the perspectives of African Americans. A genuine good White-in the mental construct of the Blacks-is one who truly stands against marginalisation and the injustice inflicted on black people. This brings to mind the story of the white teachers who endured humiliation by their fellow whites for teaching in black schools in some southern states in the United States; the many white academicians and journalists who have used their careers to expose racial injustice; the many white people who stood against apartheid in South Africa despite being ostracised by their fellow Whites ${ }^{69}$ the massive presence of white people in BlackLivesMatter protests in Europe and America and similar other cases.

By identifying with the protesting oppressed, the sympathiser also fights white supremacy. The sympathiser in the philosophy of BCM is also Black. In this philosophy, blackness does not connote the pigmentation of one's skin but an attitude and anybody who identifies himself with the black struggle is Black. ${ }^{70}$ There is no middle ground in the struggle. Many white people chose to use their privileges to support anti-apartheid protests in South Africa despite the backlash from not only police but also ordinary white people. For instance, Bram Fischer betrayed Afrikaner nationalism and defended Nelson Mandela in $1963 .{ }^{71} \mathrm{He}$ chose to be Black and that earned him life imprisonment and suffering with fellow Blacks in prison. Other white activists against apartheid were Denis Goldberg, Jeremy Cronin, Raymond Suttner, Ruth First, Hellen Joseph, Beyers Naudé and Joe Slovo. Whites with such an attitude, it can be said, are not only the Ebed-Melechs of Jeremiah but co-singers in the chorus-

68 Mabogo More, "Black Consciousness Movement's Ontology: The Politics of Being," Philosophia Africana (2012): 23-39; Mgwebi Snail, "The Black Consciousness Movement in South Africa: A Product of the Entire Black World," HAOL 15(2008): 51-68.

69 Paul Rich, "Whites against Apartheid," South African Historical Journal 32 (1995): 206-217.

70 Mgwebi Snail, "The Black Consciousness Movement in South Africa," 55.

71 Stephen Clingman, "Afrikaner Revolutionary Revisited: Bram Fischer in our Times," International Journal of Postcolonial Studies 22(7), https://doi.org/10.1080/1369801x.2020.1762697. 
"I am black and beautiful." It has to be emphasised that as the oppressed, Blacks must be the ones to lead the protests and decide the role of the sympathiser.

The efficacy of protests is that they bring embarrassment to the oppressor. Protests of all sorts expose the rotten underbelly and hypocrisy of the oppressor. In a bid to calm the protest, oppressors would often apply force and violence to intimidate the oppressed. Key protest voices will always be the target, as witnessed in the assassination of public figures such as Martin Luther King, Jr. in 1968 and Stephen Biko and many others in South Africa. Positive protests mount pressure that weakens the credibility of the oppressors, forcing them to re-examine their tenets in the face of public opinion and international relations. This was the case in various anti-apartheid protests in South Africa that eventually witnessed the release of Nelson Mandela and the end of apartheid. In recent BLM protests, various symbols of racism and slavery were removed from various city squares and capital buildings across Europe and the United States. The demolition of statues and monuments demonstrate that the oppressors are embarrassed about their own antecedents that inform their racist attitudes and privileges and bring to question the ideologies that ensconce their reified propensities to oppress people of other races. In Ebed-Melech's protest, King Zedekiah seems to rethink his stake in the arrest of Jeremiah - the oppressedand ordered for his immediate release.

Desmond Tutu will always be remembered for saying, "If you are neutral in situations of injustice, you have chosen the side of the oppressor. If an elephant has its foot on the tail of a mouse, and say that you are neutral, the mouse will not appreciate your neutrality." The reading of Song of Songs 1:5-7, like Jer $38: 1-17$, is to challenge the ambivalent audience about the dominant knowledge values and stereotypes that nourish racism. Africans today are faced with the daunting task of redefining their image and dealing with the dominant structures that hold them captive to perpetual poverty and marginalisation. The biblical text of Song of Songs in the contemporary context becomes a means by which an African soul calls for the re-examination of Africa's poverty and technological challenges in historical terms. It appeals to the polity that examines and articulates in sincere terms the plight of black people all over the world whilst calling for freedom from the historical and contemporary terms that have transfigured a black person into the socio-economic other. As King Zedekiah did in the case of Jeremiah, guilt, which often manifests in the form of repression of Blacks, should take a positive dimension that would address racist systems and attitudes. Song of Songs 1:5-7, read in this way, serves to reaffirm our humanity, dignity, value and pride as black people. Black people should define themselves and protest against being defined by others in dehumanising and marginalising ways. We are black and beautiful! 


\section{G BIBLIOGRAPHY}

Adamo, David T. and E.F. Eghwubare. "The African Wife of Abraham (Gn 16:1-16; 21:8-21)." Old Testament Essays 18/3 (2005): 455-471.

. "Ebed-Melech's Protest to King Zedekiah as a Model of Modern Protest Movement (Jr. 38:1-17)." In die Skriflig 53(1). a2450. https://doi.org/10.4102/ids.v53i1.2450.

."The Portrayal of Africa and Africans in the Book of Jeremiah." In die Skriflig 52(1). https://doi.org/10.4102/ids.v52i1.2259.

. "What Is African Biblical Hermeneutics?" Black Theology 13/1 (2015): 5972.

. "African Background of African American Liberative Hermeneutics." African Journal of Biblical Studies 20 (2004): 3-28.

Anderson, Elijah. "This Is What It Feels Like to Be Black in White Spaces." The Guardian (2018). No pages. Cited 10 July 2020. Online: https://www.theguardian.com/commentisfree/2018/jun/09/everyday-racismamerica-black-white-spaces. ."The White Space." Sociology of Race and Ethnicity 1/1 (2015): 10-21.

Adesina, Precious. "The Birth of the Black Is Beautiful Movement." BBC. No Pages. Cited 15 July 2020. Online: https://www.bbc.com/culture/article/20200730the-birth-of-the-black-is-beautiful-movement.

Arwa Haider. "The Art of Protest: White Riot: The Music Activists Who Took on Racism." BBC Documentary. No Pages. Cited 14 July 2020. Online: https://www.bbc.com/culture/article/20200819-white-riot-the-music-activistswho-took-on-racism.

Bjorgo, Tore. "Role of Media in Racist Violence." Pages 96-112 in Racist Violence in Europe. Edited by Tore Bjorgo and R. Witte. London: Palgrave Macmillan, 1993.

Brunsma, L. David and Kerry Anne Rockquemore. "What Does "Black" Mean? Exploring the Epistemological Stranglehold of Racial Categorization." Critical Sociology 28/1-2 (2002): 101-121.

Burke, Marcus. "How the Media and Entertainment Industry Is Addressing Systematic Racism." World Economic Forum. No pages. Cited 30 July 2020. Online: https://www.weforum.org/agenda/2020/07/how-media-and-entertainmentadvertising-consumer-products-sports-industry-is-addressing-systematicracism/.

Carleton Nicholas R. "Fear of the Unknown: One Fear to Rule Them All?" Journal of Anxiety Disorders 41 (2016): 5-21.

Chana Bloch, "Shulammite: Bible." JWA. No Pages. Cited 14 June 2020. Online: https://jwa.org/encyclopedia/article/shulammite-bible.

Christina, Henderson. "Sympathetic Violence: Maria Stewart's Antebellum Vision of African American Resistance." Mult-Ethnic Literature of the United States 38/4 (2013): 52-75.

Clingman Stephen, "Afrikaner Revolutionary Revisited: Bram Fischer in our Times." International Journal of Postcolonial Studies 22/7 (2020). 14 pages. https://doi.org/10.1080/1369801x.2020.1762697.

Eligon, John. "Black Doctor Dies of Covid-19 after Complaining of Racist Treatment." The New York Times. No Pages. Cited 12 March 2021. Online: 
http://www.nytimes.com/2020/12/23/us/susan-moore-black-doctorindiana.html.

Fischer, J. Mary. "Interracial Contact and Changes in Racial Attitude of White College Students." Social Psychology of Education 14 (2011): 547-574.

Gathmann Sandra. "What Does It Mean to Be Black in America?" In Al Jazeera. Viewed 15 June 2020.2 Online: https://www.youtube.com/watch?v=4NgkJJzzk8Q.

Haggis, Paul. "Crash.” DVD. Los Angeles, 2004.

Hill L. Shannen. Biko's Ghost: The Iconography of Black Consciousness. Minneapolis: MUP, 2015.

Hinton, Elizabeth, LeShae Henderson and Cindy Reed. An Unjust Burden: The Disparate Treatment of Black Americans in the Criminal Justice System. New York: Vera Institute of Justice, 2018.

Holter, Knut. "Africa in the Old Testament." Pages 569-581 in The Bible in Africa: Transactions, Trajectories and Trends. Edited by Musa Dube and Gerald O. West. Boston: Brill, 2000.

Hopkins N. Dwight. "Enslaved Black Women: A Theology of Justice and Reparations." Pages 287-306 in Beyond Slavery: Overcoming Its Religious and Sexual Legacies. Edited by Bernadette J. Brooten and Jacqueline L. Hazelton. New York: Palgrave Macmillan, 2010.

Howarth, Caroline. "Race and Stigma: Positioning the Stigmatized as Agents, not Objects." Journal of Community and Applied Social Psychology 16/6 (2006):442-451.

LeDoux, E. Joseph. "Coming to Terms with Fear." Proceedings of the National Academy of Sciences of the United States of America 111/8 (2014). 8 Pages. https://doi.org/10.1073/pnas.1400335111.

Lenhardt, A. Robin. "Understanding the Mark: Race, Stigma and Equality in Context." New York University Law Review 79 (2004): 803-931.

Litwark, F. Leon. "The White Man's Fear for the Educated Negro: How the Negro Was Fitted for His Natural and Logical Calling." The Journal of Blacks in Higher Education 20 (1998): 100-108.

Lopez, Laura A. "Who Named Slaves and Their Children? Names and Naming Practices among Enslaved Africans Brought to the Americas and Their Descendants with Focus on Brazil." Journal of African Cultures and Studies 27/2 (2015): 159-171.

Loury, C. Glenn. "Racial Stigma and Its Consequences.” Focus 24/1 (2005): 1-6.

Lyles-Scott, Cynthia. "A Slave by Any Other Name: Names and Identity in Toni Morrisons's Beloved." Journal of Onomastics 56/1 (2008): 23-28.

Maquita, Peters. "Being Black In America: 'We Have a Place in This World Too.", NPR Magazine. No Pages. Cited 15 July 2020. Online: https://www.npr.org/2020/06/05/867060621/being-black-in-america-we-havea-place-in-this-world-too.

More, Mabogo. "Black Consciousness Movement's Ontology: The Politics of Being." Philosophia Africana (2012): 23-39.

Morrison, Toni. The Bluest Eye. New York: Vintage Book International, 2007.

Neal-Barnett, Angela. "To Be Female, Anxious and Black." Anxiety and Depression Association of America. Cited 10 July 2020. Online: https://adaa.org/learnfrom-us/from-the-experts/blog-posts/consumer/be-female-anxious-and-black 
Nyamnjoh, B. Francis. "Racism, Ethnicity and the Media in Africa: Reflections Inspired by Studies of Xenophobia in Cameroon and South Africa." Africa Spectrum 1 (2010): 57-93.

Panksepp, Jaak. "Fear and Anxiety Mechanisms of the Brain: Clinical Implications." Pages 155-177 in Principles of Medical Biology. Edited by E. Edward Bittar and Neville Bittar. Amsterdam: Elsevier, 2000.

Rastas, Anna and Elina Seye. "Music and Anti-Racism: Musicians' Involvement in Anti-racist Spaces." Popular Music and Society 42/5 (2019): 592-610.

Rich, Paul. "Whites against Apartheid." South African Historical Journal 32 (1995): 206-217.

Richardson, Marilyn, ed. America's First Black Woman Political Writer: Essays and Speeches, Indiana University Press, 1987.

Ricoeur, Paul. "Appropriation." Pages 144-156 in Hermeneutics and the Human Sciences: Essays on Language, Action and Interpretation. Edited by John B. Thompson. Cambridge Philosophy Classics. Cambridge: Cambridge University Press, 2016.

Riezler, Kurt. "The Social Psychology of Fear." The American Journal of Sociology 49/6 (1944): 489-498.

Rodney, Walter. How Europe Under-developed Africa. London: Bogle-L'Ouverture, 1973.

Rugwiji, Temba. "Appropriating Judean Postexilic Literature in a Postcolonial Discourse: A Case for Zimbabwe." PhD Thesis, University of South Africa, 2013.

. "The Quest for Hermeneutics of Appropriation as a Thematic Approach for Critical Biblical Interpretation.” HTS Teologiese Studies/Theological Studies 76(1). https://doi.org/10.4102/hts.v76i1.5392.

Sasson, Victor. "King Solomon and the Dark Lady in the Song of Songs." Vetus Testamentun 39/4 (1989): 407-414

Sawyer, Jeremy and Anup Gampa. "Implicit and Explicit Racial Attitudes Changed during Black Lives Matter." Personality and Social Psychology Bulletin 44/7 (2018): 1039-1059.

Sigelman, Lee and Susan Welch. "The Contact Hypothesis Revisited: Black-White Interaction and Positive Racial Attitudes." Social Forces 71/3 (1993): 781-795.

Snail, Mgwebi. "The Black Consciousness Movement in South Africa: A Product of the Entire Black World." Historia Actual OnLine 15 (2008): 51-68.

Solanke, Iyiola. "The Stigma of Being Black in Britain." Identities 25/1 (2018): 49-54.

Taylor, Marylee C. and Peter J. Mateyka. "Community Influences on White Racial Attitudes: What Matters and Why?" The Sociological Quarterly 52/2 (2011): 220-243.

Turner, Claudine and Liz Grauerholz. "Introducing the Invisible Man: Black Male Professionals in Higher Education." Humboldt Journal of Social Relations 1/39 (2017): 212-227.

Ullendorff Edward. Ethiopia and the Bible. Schweich Lectures. London: The British Academy and Oxford University Press, 2009.

Wabyanga, R. Kuloba. "Song of Songs 1:5-7: The Africana Reading." Journal for Theology for Southern Africa 150/1 (2014): 128-147.

Warden, H. James. Black in the Bible: The Original Roots of Men and Women of Color in Scripture. London: AuthorHouse, 2006. 
Westbrook C. Dmitric. “Opinion Editorial: Why Is It that So Many White People Fear Black Men?” College Student Affairs Leadership 1/2 (2014): Article 4.

Young Robert J.C. Postcolonialism: A Very Short Introduction. New York: Oxford University Press, 2003.

Dr Robert Kuloba Wabyanga, Kyambogo University, email: robert_kuloba@yahoo.com. ORCID: https://orcid.org/0000-0001-6589-551X 